\title{
An economic analysis of the political promotion system in China $^{* 1}$
}

\author{
Jiancai $P i^{2}$
}

\begin{abstract}
This paper mainly discusses the political promotion system in China. Specifically, we develop a generalized analytical framework by introducing the contest success function. On the one hand, the central government can give the optimal political promotion benefits to local officials to incentivize them to exert desirable developmental efforts. On the other hand, the central government can undertake a further design of the political promotion system to motivate local officials via its assigned incentive strengths to the corresponding group and other groups, or via its stipulated number of comparable regions in the corresponding group. Our main findings in terms of the local official's assigned weight to the political benefit are as follows. First, the individual developmental effort and the summed developmental efforts are increasing in the local official's assigned weight to the political benefit. Second, the central government's assigned incentive strength to other groups is increasing in the local official's assigned weight to the political benefit. Third, the central government's assigned incentive strength to the corresponding group is decreasing in the local official's assigned weight to the political benefit. Fourth, the number of comparable regions in the corresponding group is decreasing in the local official's assigned weight to the political benefit.
\end{abstract}

Key words: political promotion, China miracle, contest success function, promotion tournament model, local official

JEL classification: H11, P35, R50

\footnotetext{
* Received: 18-08-2017; accepted: 21-12-2017

1 This work has been supported by the National Social Science Fund of China under the funding programme (project title: Endogenous identification and classified governance of institutional over-capacity in the supply-side structural reform of China; code: 16BJY080; acronym: NSSFC; project manager: Jiancai Pi).

2 Full Professor of Economics, Department of Economics, School of Business, Nanjing University, 22 Hankou Road, Nanjing 210093, China. Scientific affiliation: organizational economics, development economics.Phone: +862583621121(O).E-mail:pi2008@nju.edu.cn.
} 


\section{Introduction}

China has achieved a high rate of economic growth and a good outcome of economic performance for a long period, which is called "China Miracle" by many economists and journalists. Different theoretical studies (e.g., Lin et al., 1993; Qian and Xu, 1993; Montinola et al., 1995; Lin and Liu, 2000; Tsui and Wang, 2004; Jin et al., 2005; Cai and Treisman, 2006; Yao, 2008; Lin, 2009; He and Yao, 2011; Caldeira, 2012; Zhang, 2012a, 2012b; Gilli and Li, 2013) have put forward different viewpoints to explain the political foundation behind "China Miracle" from different perspectives. The role of governments at various levels are analyzed in depth, and almost all the existing studies greatly stress the role of the central and local governments in initiating and maintaining the miraculous development of the Chinese economy.

For example, Blanchard and Shleifer (2001) find the angle of Chinese-style decentralization, and highlight that the Chinese-style combination of political centralization and economic decentralization plays a crucial role. As Blanchard and Shleifer (2001, p.176) ingeniously point out, "With respect to China, our analysis implies that, to the extent that federalism has played a helpful role in promoting China's economic growth, such federalism relied crucially on the centralizing role of the Communist party." By the words of Frye and Shleifer (1997), political centralization can change the local governments" "grabbing hands" to "helping hands." Xu (2011, p. 1078) originally terms the Chinese-style decentralization as the Chinese regionally decentralized authoritarian (RDA) regime, and gives a more accurate and thorough description and puts it in another way, "On the one hand, the national government's control is substantial in that the Chinese political and personnel governance structure has been highly centralized. Subnational government officials are appointed from above, and the appointment and promotion of subnational government officials serve as powerful instruments for the national government to induce regional officials to follow the central government's policies. This feature fundamentally distinguishes the Chinese RDA regime from federalism, where governors or mayors are elected and they are supposed to represent and be accountable to their constituents. On the other hand, the governance of the national economy is delegated to subnational governments. Regional economies (provinces, municipalities, and counties) are relatively self-contained, and subnational governments have overall responsibility for initiating and coordinating reforms, providing public services, and making and enforcing laws within their jurisdictions." Gilli and Li (2013, p. 470) stress the role of reciprocal accountability, and they point out, "This dramatic transition was successful because the selectorate had efficiently constrained autocratic power with internal checks and balances which gave policy makers an incentive to promote economic growth."

In the background of China, when the role of the central and local governments is mentioned, the political promotion system should be placed in an important 
position. It is such a system that provides the incentives for local officials. The purpose of this paper is to provide an economic analysis of the political promotion system in China.

This paper hypothesizes that the central government can affect the behaviors of local officials through a series of policy tools in the framework of the political promotion system in China. Specifically, the central government can give the optimal political promotion benefits to local officials to incentivize them to exert desirable developmental efforts. Besides, the central government can undertake a further design of the political promotion system to motivate local officials via its assigned incentive strengths to the corresponding group and other groups, or via its stipulated number of comparable regions in the corresponding group. We will use the game-theoretical model to prove our hypothesis.

The rest of the paper is organized as follows. Section 2 provides the literature review in this field. Section 3 establishes the analytical model based on the contest success function. Section 4 offers the main results and discusses the design of the political promotion system in China. Section 5 provides some concluding remarks and points out several potential extensions.

\section{Literature review}

The literature most related to this paper is one of the most famous and popular explanations in China, which is termed as the "promotion tournament model." This model is firstly advanced and coined by Zhou (2004, 2007, 2008). Zhou argues that promotion tournaments can serve as a good incentive mechanism to govern and incentivize Chinese local officials. Specifically, in the promotion tournaments, different local officials from different regions try their best to push forward their own jurisdictions' economic development through using the resources that are manipulated by them. In order to formalize the above-mentioned idea in an integrated mathematical framework, Zhou (2004) borrows from Lazear and Rosen (1981) to build up his formal model. Although Zhou and his coauthors provide evidence to empirically support their theoretical hypothesis (see, e.g., Chen et al., 2005; Li and Zhou, 2005), there are several queries on Zhou's model (see, e.g., Tao et al., 2009, 2010; Su et al., 2012). Firstly, although it is theoretically predicted that the local official whose economic performance is better will be promoted, in the real world local officials whose economic performance is poorer may also be promoted. Secondly, different local officials may have different political networks or factional ties (see e.g., Shih et al., 2012), which may play an important role that is greatly neglected by Zhou's model. All these limitations of Zhou's model tell us that the tournament tool based on Lazear and Rosen (1981) is not a perfectly suitable one in providing a sound political foundation. 
Greatly different from Zhou's (2004) model, this paper tries to borrow from Tullock's (1980) original idea to build a new model based on the stylized facts in China. The models of the contest success function have been well-developed and applied by many scholars (see, e.g., Skaperdas, 1996; Baik, 1998; Dasgupta and Nti, 1998; Rai and Sarin, 2009; Corchón and Dahm, 2010). In this paper, we will show that Tullock's conceptual framework can be used to construct an economic theory of the political promotion system in China.

This paper can be seen as an extension of Pi (2012). The differences between this paper and Pi (2012) are reflected in the following respects. Firstly, Pi (2012) focuses mainly on the role of political networks by introducing a bias-coefficient, which favors the network-connected local officials and discriminates against the unconnected local officials. However, this paper neglects the role of political networks in Pi's (2012) sense. Secondly, Pi (2012) assumes that there are one central government and two regions, and that each region has only one representative local official. However, this paper supposes that there are one central government and $N$ regions, where $N \geq 2$. In other words, Pi (2012) takes the number of regions or local officials in the same contest as given, but this paper looks upon the number of regions or local officials as a policy tool of the central government. Through designing the size of the contest in the political promotion, the central government can achieve some desirable outcomes. Thirdly, the local official's assigned weights to the political benefit and the private benefit are treated in different ways. In Pi (2012), the sum of the assigned weights is not taken as a constant, however, in this paper the sum of the assigned weights is taken as a constant. Pi (2012) aims at exploring the independent effects of the assigned weights, while this paper tries to investigate the dependent effects of the assigned weights. More importantly, the tradeoff related to the assigned weights neglected by Pi (2012) can be thoroughly examined in this paper.

Here, it should be noted that there are some studies giving deep-seated supports for this paper. For example, Groves et al. $(1995$, p. 889) find that "improved managerial selection can occur under the aegis of the bureaucratic system. As such, the development of nascent managerial labor markets can play an important subsidiary role in the overall transition to a market economy." Such kind of evidence lays the foundation for concept of the local official's developmental effort. According to Cao et al. (2017, p. 13), "although forced turnover of nonpolitically connected CEOs leads to performance improvement in all firms, forced turnover of politically connected CEOs leads to performance improvement only in firms that are politically advantaged." This shows that the efficiency of the local official's developmental effort may depend on the types of political connection. In the new situation, the local official's developmental effort needs to keep pace with the times. 


\section{Model of analysis}

In order to capture the stylized facts in China, we use a dynamic game to depict the political promotion system. There are two kinds of players, namely the central government and local officials. The central government and local officials play a two-stage dynamic game. At the first stage, the central government chooses its policy action to incentivize local officials to promote economic growth in their own jurisdictions. At the second stage, local officials simultaneously choose their effort levels to maximize their utility functions. The game can be analyzed by backward induction.

There are two types of efforts that can be exerted by each local official, namely the developmental effort and the non-developmental effort, and both developmental and non-developmental efforts can be taken at the same time. The developmental effort can be used to give an impetus to the local jurisdiction's economic development, while the non-developmental effort can be used to produce some kind of private benefit for the local official. Each local official's total effort is $\bar{e}$, which is the sum of his developmental and non-developmental efforts. When the local official exerts one unit of effort, no matter whether developmental or nondevelopmental, he will be incurred a unit cost of $\theta$. If the local official expends the developmental effort, he will obtain a political promotion benefit $G$ with a probability determined by the contest success function. One unit of developmental effort will produce one unit of efficacy of economic development (e.g., one unit of economic growth rate or one unit of fiscal revenue). However, when the local official exerts the non-developmental effort, he will get a private benefit with certainty. One unit of non-developmental effort will generate $V$ units of private benefit. The private benefit may be legal or illegal in the background of transition. When the central government launches the anti-corruption campaign, the private benefit will tend to appear in the form of being legal. The local official assigns a weight of $\alpha$ to the political benefit, and a weight of $1-\alpha$ to the private benefit, where $0<\alpha<1$. Different values of $\alpha$ reflect that the local official may have different promotional prospects or value orientations.

We suppose that there are $N \geq 2$ regions, and that each region has only one representative local official. Local official $i$ in region $i$ exerts developmental effort $e_{i}$, and the sum of developmental efforts exerted by other local officials in other regions is expressed by $e_{-i}$, where $e_{-i}=\sum_{j \neq i} e_{j}$. For simplicity, we assume that one unit of developmental effort can yield one unit of output. According to Zhou (2004) and Pi (2012), these $N$ regions can be seen as a group of comparable jurisdictions, that is to say, local officials of these $N$ regions undertake a contest to get the political promotion benefit $G$ (e.g., higher political positions or better treatment) that is offered by the central government. Here, the political promotion benefit $G$ can 
be seen as the central government's policy action and is subject to a total amount restriction, but it does not constitute the central government's costs. Moreover, comparable jurisdictions are an important terminology coined by Zhou (2004), which are defined on the basis of the administrative relation and the geographical pattern. Zhou (2004) uses this terminology in the sense that the external shocks are common or similar to the jurisdictions in the same group when different local officials exerts developmental efforts to promote economic growth.

The contest success function of local official $i$ in region $i$ is:

$$
p_{i}=\frac{e_{i}}{e_{i}+e_{-i}} .
$$

Equation (1) shows that each local official has a positive probability to succeed and win the political promotion benefit as long as he exerts a positive developmental effort.

Local official $i$ 's utility function can be expressed as:

$$
Y_{i}=(1-\alpha)\left(\bar{e}-e_{i}\right) V+\alpha p_{i} G-\theta \bar{e},
$$

where $\bar{e}-e_{i}$ denotes local official $i$ 's non-developmental effort. In order to make our analysis interesting, we assume that $\bar{e}>\frac{(N-1) \alpha G}{N^{2}(1-\alpha) V}$.

Substituting Equation (1) into Equation (2), we can obtain:

$$
Y_{i}=(1-\alpha)\left(\bar{e}-e_{i}\right) V+\frac{\alpha G e_{i}}{e_{i}+e_{-i}}-\theta \bar{e} .
$$

According to the first-order condition of Equation (3) and using the symmetry of local officials, we can get local official $i$ 's developmental effort level:

$$
e=\frac{(N-1) \alpha G}{N^{2}(1-\alpha) V}
$$

Here, it should be noted that $e$ in Equation (4) is independent of $\theta$ because developmental and non-developmental efforts are addable and separable and at the same time their sum is a constant $\bar{e}$.

From Equation (4), we can obtain the sum of total developmental efforts of $N$ local officials:

$$
E=N e=\frac{(N-1) \alpha G}{N(1-\alpha) V}
$$


The central government can provide a total political promotion benefit $\bar{G}$ to all the local officials in different contests, but in the same contest it can only assign $G$ to the corresponding group of comparable jurisdictions which is composed of $N$ regions, and the remainder $\bar{G}-G$ will be assigned to other groups of comparable jurisdictions. On the one hand, the central government needs to incentivize local officials in the corresponding group to exert the developmental effort as much as possible, and it assigns an incentive strength $\rho$ to the corresponding group. On the other hand, as there are other groups, the central government also needs to incentivize local officials in these groups, and it assigns an incentive strength $\mu$ to these groups.

Thus, the utility function of the central government can be expressed as:

$$
U=\mu \ln (\bar{G}-G)+\rho \sum_{i=1}^{N} e_{i} .
$$

There are three points that should be noted. Firstly, $\rho$ and $\mu$ are independent, which reflects that the fact that central government will give different incentive strengths to fundamentally different groups that are distinguished by the corresponding group and the non-corresponding groups. The difference of incentive strengths is determined by the fact that different groups have different initial conditions and development opportunities. Secondly, as for the political promotion benefit, we set the utility function of local officials (i.e., Equation (2)) as linear and the utility function of the central government (i.e., Equation (6)) as log-linear. The logic behind this setting is that rank-oriented local officials take the political promotion benefit as "political money" that generates constant marginal utility, while the development-oriented central government treats the political promotion benefit as a normal good that engenders diminishing marginal utility.

Thirdly, the central government care about the total outputs, which is an important characteristic of the developmental state (see e.g., Wade, 1990; Nee et al., 2007; Riskin, 2009; Knight and Ding, 2012; Knight, 2014) and constitutes the cornerstone of the political promotion system in China.

Substituting Equation (5) into Equation (6), we can obtain:

$$
U=\mu \ln (\bar{G}-G)+\frac{(N-1) \alpha G}{N(1-\alpha) V} .
$$

From the first-order condition of Equation (7), we can get the equilibrium value of $G$ :

$$
G^{*}=\bar{G}-\frac{N(1-\alpha) \mu V}{(N-1) \alpha \rho} .
$$

Throughout the paper, we use the superscript * to denote the equilibrium state. 


\section{Results and discussion}

In this section, we will give the fundamental results and discuss how to design the political promotion system in China.

\subsection{Fundamental results}

Based on Equation (8), we can obtain Proposition 1.

Proposition 1: $\frac{\partial G^{*}}{\partial N}<0, \frac{\partial G^{*}}{\partial \alpha}>0, \frac{\partial G^{*}}{\partial \mu}<0, \frac{\partial G^{*}}{\partial \rho}>0, \frac{\partial G^{*}}{\partial V}<0$.

Proof: From Equation (8), it is easy to obtain:

$$
\begin{aligned}
\frac{\partial G^{*}}{\partial N} & =\frac{(1-\alpha) \mu V}{(N-1)^{2} \alpha \rho}>0, \frac{\partial G^{*}}{\partial \alpha}=\frac{N \mu V}{(N-1) \alpha^{2} \rho}>0, \\
\frac{\partial G^{*}}{\partial \mu} & =-\frac{N(1-\alpha) V}{(N-1) \alpha \rho}<0, \frac{\partial G^{*}}{\partial \rho}=\frac{N(1-\alpha) \mu V}{(N-1) \alpha \rho^{2}}>0, \\
\frac{\partial G^{*}}{\partial V} & =-\frac{N(1-\alpha) \mu}{(N-1) \alpha \rho}<0 .
\end{aligned}
$$

There is one point about $N$ worth mentioning. Although $N$ is not continuous in rigorously mathematical sense, we can treat it as if continuous. Such kind of treatment is very prevalent in the existing literature (e.g., endogenous entry) that uses game theory as an analytical tool.

Proposition 1 implies that the equilibrium assigned political promotion benefit is decreasing in the number of comparable regions in the corresponding group, the central government's assigned incentive strength to other groups, and the local official's private benefit, but increasing in the local official's assigned weight to the political benefit, and the central government's assigned incentive strength to the corresponding group.

Substituting Equation (8) into Equation (4), we can get:

$$
e^{*}=\frac{(N-1) \alpha}{N^{2}(1-\alpha) V}\left[\bar{G}-\frac{N(1-\alpha) \mu V}{(N-1) \alpha \rho}\right] .
$$

Substituting Equation (8) into Equation (5), we can obtain:

$$
E^{*}=\frac{(N-1) \alpha}{N(1-\alpha) V}\left[\bar{G}-\frac{N(1-\alpha) \mu V}{(N-1) \alpha \rho}\right]
$$


Based on Equations (9) and (10), we can obtain Proposition 2.

Proposition 2: (i) $\frac{\partial e^{*}}{\partial \alpha}>0, \frac{\partial e^{*}}{\partial V}<0, \frac{\partial e^{*}}{\partial N} \leq 0$, (ii) $\frac{\partial E^{*}}{\partial \alpha}>0, \frac{\partial E^{*}}{\partial V}<0, \frac{\partial E^{*}}{\partial N}>0$.

Proof: (i) From Equation (9), it is easy to obtain:

$$
\begin{aligned}
\frac{\partial e^{*}}{\partial \alpha} & =\frac{(N-1) \bar{G}}{N^{2}(1-\alpha)^{2} V}>0, \frac{\partial e^{*}}{\partial V}=-\frac{(N-1) \alpha \bar{G}}{N^{2}(1-\alpha) V^{2}}<0, \\
\frac{\partial e^{*}}{\partial N} & =-\frac{(N-2) \alpha \bar{G}}{N^{3}(1-\alpha) V} \leq 0 .
\end{aligned}
$$

(ii) From Equation (10), it is easy to get:

$$
\begin{aligned}
\frac{\partial E^{*}}{\partial \alpha} & =\frac{(N-1) \bar{G}}{N(1-\alpha)^{2} V}>0, \frac{\partial E^{*}}{\partial V}=-\frac{(N-1) \alpha \bar{G}}{N(1-\alpha) V^{2}}<0, \\
\frac{\partial E^{*}}{\partial N} & =\frac{\alpha \bar{G}}{N^{2}(1-\alpha) V}>0 .
\end{aligned}
$$

From Proposition 2, we know that at equilibrium both the individual developmental effort and the summed developmental efforts are increasing in the local official's assigned weight to the political benefit, and decreasing in the local official's private benefit. However, at equilibrium the individual developmental effort is decreasing in the number of comparable regions in the corresponding group, but in contrast, the summed developmental efforts are increasing in the number of comparable regions in the corresponding group.

Both Proposition 1 and Proposition 2 fit in well with our economic intuition, which provides a sound ground for the design of the political promotion system in China that will be explored in the following section.

\subsection{Discussion of the political promotion system}

In this subsection, we will discuss the design of the political promotion system in China.

We treat the two-stage dynamic game in Section 2 as a subgame of a bigger game, and pay our attention to the central government's political promotion design. Before the game in Section 2 is played, the central government firstly moves, who chooses its assigned incentive strength to other groups $(\mu)$, or its assigned incentive strength to the corresponding group $(\rho)$, or its stipulated number of regions in the corresponding group $(N)$. In this bigger game, the central 
government has the power to design the political promotion system. There is no commitment problem both on the side of the central government and on the side of local officials. That is to say, neither the central government nor local officials will violate the contract terms. In order to solve this bigger game, we still use backward induction.

Substituting Equation (8) into Equation (7), we can obtain:

$$
U=\mu \ln \left[\frac{N(1-\alpha) \mu V}{(N-1) \alpha \rho}\right]+\frac{(N-1) \alpha \rho}{N(1-\alpha) V}\left[\bar{G}-\frac{N \alpha \mu V}{(N-1) \alpha \rho}\right] .
$$

Given $\rho$ and $N$, differentiating Equation (11) with respect to $\mu$, we can get:

$$
\mu^{*}=\frac{(N-1) \alpha \rho}{N(1-\alpha) V}
$$

On the basis of Equation (12), we can obtain Proposition 3.

Proposition 3: $\frac{\partial \mu^{*}}{\partial \alpha}>0, \frac{\partial \mu^{*}}{\partial \rho}>0, \frac{\partial \mu^{*}}{\partial V}<0, \frac{\partial \mu^{*}}{\partial N}>0$.

Proof: From Equation (12), it is easy to obtain:

$$
\begin{aligned}
& \frac{\partial \mu^{*}}{\partial \alpha}=\frac{(N-1) \rho}{N(1-\alpha)^{2} V}>0, \frac{\partial \mu^{*}}{\partial \rho}=\frac{(N-1) \alpha}{N(1-\alpha) V}>0, \\
& \frac{\partial \mu^{*}}{\partial V}=-\frac{(N-1) \alpha \rho}{N(1-\alpha) V^{2}}<0, \frac{\partial \mu^{*}}{\partial N}=\frac{\alpha \rho}{N^{2}(1-\alpha) V}>0 .
\end{aligned}
$$

Proposition 3 implies that at equilibrium the central government's assigned incentive strength to other groups is increasing in the local official's assigned weight to the political benefit, and the central government's assigned incentive strength to the corresponding group and the number of comparable regions in the mentioned group, but decreasing in the local official's private benefit.

Given $\mu$ and $N$, differentiating Equation (11) with respect to $\rho$, we can get:

$$
\rho^{*}=\frac{(1-\alpha) \mu N V}{(N-1) \alpha \bar{G}} .
$$

Based on Equation (13), we can obtain Proposition 4.

Proposition 4: $\frac{\partial \rho^{*}}{\partial \alpha}<0, \frac{\partial \rho^{*}}{\partial \mu}>0, \frac{\partial \rho^{*}}{\partial V}>0, \frac{\partial \rho^{*}}{\partial N}<0$. 
Proof: From Equation (13), it is easy to obtain:

$\frac{\partial \rho^{*}}{\partial \alpha}=-\frac{\mu N V}{(N-1) \alpha^{2} \bar{G}}<0, \frac{\partial \rho^{*}}{\partial \mu}=\frac{(1-\alpha) N V}{(N-1) \alpha \bar{G}}>0$,

$\frac{\partial \rho^{*}}{\partial V}=\frac{(1-\alpha) \mu N}{(N-1) \alpha \bar{G}}>0, \frac{\partial \rho^{*}}{\partial N}=-\frac{(1-\alpha) \mu V}{(N-1)^{2} \alpha \bar{G}}<0$.

Proposition 4 implies that at equilibrium the central government's assigned incentive strength to the corresponding group is decreasing in the local official's assigned weight to the political benefit and the number of comparable regions in the corresponding group, but increasing in the central government's assigned incentive strength to other groups and the local official's private benefit.

Given $\mu$ and $\rho$, differentiating Equation (11) with respect to $N$, we can get:

$$
N^{*}=\frac{\rho \alpha \bar{G}}{\rho \alpha \bar{G}-(1-\alpha) \mu V}=1+\frac{(1-\alpha) \mu V}{\rho \alpha \bar{G}-(1-\alpha) \mu V} .
$$

Here, it should be noted that we neglect the integer constraint of $N$, and such kind of treatment is common in the existing studies with endogenous entry.

Based on Equation (14), we can obtain Proposition 5.

Proposition 5: $\frac{\partial N^{*}}{\partial \alpha}<0, \frac{\partial N^{*}}{\partial \mu}>0, \frac{\partial N^{*}}{\partial \rho}<0, \frac{\partial N^{*}}{\partial V}>0$.

Proof: From Equation (14), it is easy to obtain:

$$
\begin{aligned}
& \frac{\partial N^{*}}{\partial \alpha}=-\frac{\rho \mu V \bar{G}}{[\rho \alpha \bar{G}-(1-\alpha) \mu V]^{2}}<0, \frac{\partial N^{*}}{\partial \mu}=\frac{\rho \alpha(1-\alpha) V \bar{G}}{[\rho \alpha \bar{G}-(1-\alpha) \mu V]^{2}}>0, \\
& \frac{\partial N^{*}}{\partial \rho}=-\frac{\alpha(1-\alpha) \mu V \bar{G}}{[\rho \alpha \bar{G}-(1-\alpha) \mu V]^{2}}<0, \frac{\partial N^{*}}{\partial V}=\frac{\rho \alpha(1-\alpha) \mu \bar{G}}{[\rho \alpha \bar{G}-(1-\alpha) \mu V]^{2}}>0 .
\end{aligned}
$$

Proposition 5 implies that at equilibrium the number of comparable regions in the corresponding group is decreasing in the local official's assigned weight to the political benefit, the central government's assigned incentive strength to the corresponding group, but increasing in the central government's assigned incentive strength to other groups, and the local official's private benefit.

Propositions 3-5 have plentiful policy implications. The central government can adopt suitable policy tools to incentivize local officials to promote economic development via $\mu, \rho$ or $N$. That is to say, the central government has a toolbox with different tools, which can make China's political promotion system work as efficiently as possible. 
Of course, China's political promotion system is very complex, and this paper only provides a simple description from the perspective of political economy. Although there are many variables abstracted away for the sake of simplicity, we have remained the most important variables (e.g. $\mu, \rho, N)$ that are in line with the stylized facts in China. The policy tools mentioned above are often explicitly or implicitly employed by the Chinese central government.

\section{Conclusion}

In this paper, the political promotion system in China has been explored in a theoretical way. Specifically, a generalized analytical framework has been established by introducing the contest success function. In the bigger game, on the one hand, at the second stage of the dynamic game, the central government can choose the optimal political promotion benefits to incentivize local officials; on the other hand, at the first stage of the dynamic game, the central government can undertake the further design of the political promotion system, such as choosing the optimal assigned incentive strength to the corresponding group, or the optimal assigned incentive strength to other groups, or the optimal number of comparable regions in the same contest.

There are several potential extensions for future research. Firstly, the basic model can be extended by considering the more general case that different local officials may have different production abilities in transforming their developmental efforts into the efficacy of economic development. Secondly, a more complex form of the contest success function can be adopted to reflect the fact that different local officials may have different contest abilities that are embodied by different political networks just as Pi does. Thirdly, the private benefit can be divided into two categories, namely the corrupt type and the non-corrupt type, and we can develop a more detailed model to cope with the corrupt activities. Fourthly, the system covered in this model is not peculiar to China, and the model can be adjusted in some way that allows adding elements peculiar to hierarchical rent-seeking contests. Fifthly, some empirical evidences based on Chinese panel dataset can be provided to support the theoretical conclusions. Sixthly, in the future research it will be necessary to study the government's legitimacy function of consistently delivered values, together with economic and social progress, with strict commitment to the public interest taking precedence over the form of governance. Finally, in recent years, China's policy frameworks have increasingly reflected the inherent tension between the long-standing imperative of ensuring social and political stability and the more modern objective of market liberalization. These two objectives may be in direct conflict with each other, and such kind of conflict should be incorporated into the theoretical model in the future. 


\section{References}

Baik, K. H. (1998) "Difference-form Contest Success Functions and Effort Levels in Contests", European Journal of Political Economy, Vol. 14, No. 4, pp. 685701, doi: 10.1016/S0176-2680(98)00032-9.

Blanchard, O., Shleifer A. (2001) "Federalism with and without Political Centralization: China versus Russia”, IMF Staff Papers, Vol. 48, No. Special Issue, pp. 171-179, doi: 10.2139/ssrn.236127.

Cai, H., Treisman, D. (2006) "Did Government Decentralization Cause China's Economic Miracle?”, World Politics, Vol. 58, No. 4, pp. 505-535, doi: 10.1353/ wp.2007.0005.

Caldeira, E. (2012) "Yardstick Competition in a Federation: Theory and Evidence From China", China Economic Review, Vol. 23, No. 4, pp. 878-897, doi: 10.1016/j.chieco.2012.04.011.

Cao, X., Pan, X., Qian, M., Tian, G. G. (2017) "Political Capital and CEO Entrenchment: Evidence from CEO Turnover in Chinese Non-SOEs", Journal of Corporate Finance, Vol. 42, pp. 1-14, doi: 10.1016/j.jcorpfin.2016.11.003.

Chen, Y., Li, H., Zhou, L. (2005) "Relative Performance Evaluation and the Turnover of Provincial Leaders in China", Economics Letters, Vol. 88, No. 3, pp. 421-425, doi: 10.1016/j.econlet.2005.05.003.

Corchón, L., Dahm, M. (2010) "Foundations for Contest Success Functions", Economic Theory, Vol. 43, No. 1, pp. 81-98, doi: 10.1007/s00199-008-0425-x.

Dasgupta, A. Nti, K. O. (1998) "Designing an Optimal Contest", European Journal of Political Economy, Vol. 14, No. 4, pp. 587-603, doi: 10.1016/S01762680(98)00027-5.

Frye, T., Shleifer, A. (1997) "The Invisible Hand and the Grabbing Hand", American Economic Review, Vol. 87, No. 2, pp. 254-258.

Gilli, M., Li, Y. (2013) “A Model of Chinese Central Government”, Economics of Transition, Vol. 21, No. 3, pp. 451-477, doi: 10.1111/ecot.12021.

Groves, T., Hong, Y., McMillan, J., Naughton, B. (1995). "China's Evolving Managerial Labor Market”, Journal of Political Economy, Vol. 103, No. 4, pp. 873-892, doi: 10.1086/262006.

He, D., Yao, Y. (2011), "Social Equality, the Disinterested Government and Economic Growth in China", Economic Research Journal (Jingji Yanjiu), Vol. 46, No. 1, pp. 4-17.

Jin, H., Qian, Y., Weingast, B. R. (2005) "Regional Decentralization and Fiscal Incentives: Federalism, Chinese Style”, Journal of Public Economics, Vol. 89, No. 9-10, pp. 1719-1742, doi: 10.1016/j.jpubeco.2004.11.008.

Knight, J. B. (2014) "China as a Developmental State", World Economy, Vol. 37, No. 10, pp. 1335-1347, doi: 10.1111/twec.12215. 
Knight, J., Ding, S. (2012) China 's Remarkable Economic Growth. Oxford: Oxford University Press, doi: 10.1093/acprof:oso/9780199698691.001.0001.

Lazear, E., Rosen, S. (1981) "Rank-Order Tournaments as Optimal Labor Contracts", Journal of Political Economy, Vol. 89, No. 5, pp. 841-864, doi: $10.1086 / 261010$.

Li, H., Zhou, L. (2005) "Political Turnover and Economic Performance: The Incentive Role of Personnel Control in China", Journal of Public Economics, Vol. 89, No. 9-10, pp. 1743-1762, doi: 10.1016/j.jpubeco.2004.06.009.

Lin, J. Y. (2009) Economic Development and Transition: Thought, Strategy and Viability. Cambridge: Cambridge University Press, doi: 10.1017/ CBO9780511805622.

Lin, J. Y., Cai, F., Li, Z. (1993) The China Miracle: Development Strategy and Economic Reform. Hong Kong: The Chinese University Press.

Lin, J. Y., Liu, Z. (2000) "Fiscal Decentralization and Economic Growth in China", Economic Development and Cultural Change, Vol. 49, No. 1, pp. 1-21, doi: 10.1086/452488.

Montinola, G., Qian, Y., Weingast, B. R. (1995) "Federalism, Chinese Style: The Political Basis for Economic Success in China", World Politics, Vol. 48, No. 1, pp. 50-81, doi: 10.1353/wp.1995.0003.

Nee, V., Opper, S., Wong, S. (2007). "Developmental State and Corporate Governance in China", Management and Organization Review, Vol. 3, No. 1, pp. 19-53, doi: 10.1111/j.1740-8784.2007.00061.x.

Pi, J. (2012) "The Governance of Local Officials under Chinese Style Decentralization", Economic Research Journal (Jingji Yanjiu), Vol. 47, No. 10, $14-26$.

Qian, Y., Xu, C. (1993) "Why China's Economic Reforms Differ: The M-form Hierarchy and Entry/Expansion of the Non-state Sector", Economics of Transition, Vol. 1, No. 2, pp. 135-170, doi: 10.1111/j.1468-0351.1993.tb00077.x.

Rai, B. K., Sarin, R. (2009) "Generalized Contest Success Functions”, Economic Theory, Vol. 40, No. 1, pp. 139-149, doi: 10.1007/s00199-007-0328-2.

Riskin, C. (2009) "China and the (Human) Developmental State", In Sanyal, M., Amin, S. eds., Post-Reform Development in Asia: Essays in Honour of Prof. Amiya K. Bagchi, Hyderabad: Orient Black Swan.

Shih, V., Adolph, C., Liu, M. (2012) "Getting Ahead in the Communist Party: Explaining the Advancement of Central Committee Members in China", American Political Science Review, Vol. 106, No. 1, pp. 166-187, doi: 10.1017/ S0003055411000566.

Skaperdas, S. (1996) “Contest Success Functions”, Economic Theory, Vol. 7, No. 2, pp. 283-290, doi: 10.1007/BF01213906.

Su, F., Tao, R., Xi, L., Li, M. (2012) 'Local Officials' Incentives and China's Economic Growth: Tournament Thesis Reexamined and Alternative Explanatory 
Framework", China \& World Economy, Vol. 20, No. 4, pp. 1-18, doi: 10.1111/j.1749-124X.2012.01292.X.

Tao, R., Lu, X., Su, F., Wang, H. (2009) "China's Transition and Development Model under Evolving Regional Competition Patterns", Economic Research Journal (Jingji Yanjiu), Vol. 44, No. 7, pp. 21-33.

Tao, R., Su, F., Lu, X., Zhu, Y. (2010) "Can Economic Growth Lead to Promotion? A Logical Challenge to the Tournament Thesis and a Re-evaluation of Provincial Level Evidence", Management World (Guanli Shijie), No. 12, pp. $13-26$.

Tullock, G. (1980) "Efficient Rent Seeking”, In Buchanan, J., Tollison, R., Tullock, G. eds., Toward a Theory of the Rent-Seeking Society, College Station: Texas A\&M University Press, pp. 97-112.

Tsui, K., Wang, Y. (2004) "Between Separate Stoves and a Single Menu: Fiscal Decentralization in China", China Quarterly, No. 177, pp. 71-90, doi: 10.1017/ S0305741004000050.

Wade, R. (1990) Governing the Market, Princeton, N.J.: Princeton University Press.

$\mathrm{Xu}, \mathrm{C}$. (2011) “The Fundamental Institutions of China's Reforms and Development", Journal of Economic Literature, Vol. 49, No. 4, pp. 1076-1151, doi: 10.1257/ jel.49.4.1076.

Yao, Y. (2008) Economic Reform as Institutional Innovation, Shanghai: Truth \& Wisdom Press and Shanghai People's Publishing House.

Zhang, Y. (2012a) "China's Evolution toward an Authoritarian Market Economy-A Predator-Prey Model with Intelligent Design", Public Choice, Vol. 151, Nos. 1-2, pp. 271-287, doi: 10.1007/s11127-010-9747-x.

Zhang, Y. (2012b) "A View from Behavioral Political Economy on China's Institutional Change", China Economic Review, Vol. 23, No. 4, pp. 991-1002, doi: 10.1016/j.chieco.2012.05.002.

Zhou, L. (2004) "The Incentive and Cooperation of Government Officials in the Political Tournaments: An Interpretation of the Prolonged Local Protectionism and Duplicative Investments in China", Economic Research Journal (Jingji Yanjiu), Vol. 39, No. 6, pp. 33-40.

Zhou, L. (2007) "Governing China's Local Officials: An Analysis of Promotion Tournament Model”, Economic Research Journal (Jingji Yanjiu), Vol. 42, No. 5, pp. 36-50.

Zhou, L. (2008) Local Governments in Transition: Incentives and Governance of Local Officials, Shanghai: Truth \& Wisdom Press and Shanghai People's Publishing House. 


\title{
Ekonomska analiza sustava političke promocije u Kini ${ }^{1}$
}

\author{
Jiancai $P i^{2}$
}

\begin{abstract}
Sažetak
U ovom se radu istražuje sustav političke promocije u Kini. Naime, razvijen je opći analitički okvir uz uvođenje funkcije uspješnosti natjecanja. S jedne strane, središnja vlada može pogodnosti optimalne političke promocije ustupiti predstavnicima lokalne vlasti kako bi ih potaknula na dodatni napor za ostvarivanje poželjnih razvojnih ciljeva. S druge strane, središnja vlada može se obvezati na daljnje osmišljavanje sustava političke promocije kako bi motivirala predstavnike lokalne vlasti dodjeljivanjem snažnih poticaja odgovarajućoj skupini i drugim skupinama, ili putem propisanog broja usporedivih regija u odgovarajućoj skupini. Glavni rezultati ovog istraživanja u svezi su pondera političke koristi predstavnika lokalne vlasti.. Prvo, pojedinačni i ukupni razvojni napori povećavaju ponder političke koristi predstavnika lokalne vlasti. Drugo, poticajna snaga središnje vlade dodijeljene ostalim skupinama utječe na povećanje pondera političke koristi predsatvnika lokalne vlasti. Treće, poticajna snaga središnje vlade dodijeljene odgovarajućoj skupini utječe na smanjivanje pondera političke koristi predstavnika lokalne vlasti. Četvrto, broj usporedivih regija u odgovarajućoj skupini smanjuje se u odnosu na ponder političke koristi predstavnika lokalne vlasti.
\end{abstract}

Ključne riječi: politička promocija /promicanje, Kinesko čudo, funkcija uspješnog natjecanja, model promotivnog turnira, predstavnik lokalne vlasti

JEL klasifikacija: H11, P35, R50

1 Ovaj rad je financiran od strane Nacionalne zaklade za društvene znanosti u Kini, u okviru projekta "Endogenous identification and classified governance of institutional over-capacity in the supply-side structural reform of China", pod brojem 16BJY080, akronim: NSSFC; voditelj projekta: Jiancai Pi.

Zahvalan sam uredništvu i anonimnim recenzentima za korisne i detaljne komentare i prijedloge.

2 Redoviti profesor ekonomije, Department of Economics, School of Business, Nanjing University, 22 Hankou Road, Nanjing 210093, Kina. Znanstveni interes: organizacijska ekonomija, ekonomika razvoja..Tel.: +862583621121(O).E-mail: pi2008@nju.edu.cn. 